\title{
EU Humanitarian Aid after the Lisbon Treaty
}

Broberg, Morten

Published in:

Journal of Contingencies and Crisis Management

DOI:

10.1111/1468-5973.12049

Publication date:

2014

Document version

Publisher's PDF, also known as Version of record

Citation for published version (APA):

Broberg, M. (2014). EU Humanitarian Aid after the Lisbon Treaty. Journal of Contingencies and Crisis Management, 22(3), 166-173. https://doi.org/10.1111/1468-5973.12049 


\begin{tabular}{|l|l|}
\hline Journal Code: JCCM & Proofreader: Mony \\
\hline Article No: JCCM12049 & Delivery date: 22 Apr 2014 \\
\hline Page Extent: 8 & \\
\hline
\end{tabular}

\section{EU Humanitarian Aid after the Lisbon Treaty}

\section{Morten Broberg}

Faculty of Law, University of Copenhagen, Studiegaarden, Studiestraede 6, DK-1455 Copenhagen, Denmark. E-mail: ••

This paper analyses the treaty provisions introduced by the Lisbon Treaty with regard to the European Union's (EU) provision of humanitarian aid to third countries (with a particular focus on Article 214 TFEU). It first examines how the new Treaty framework affects the competences and the procedures that have been laid down with regard to humanitarian aid. It then considers the general international legal principles that, according to Article 214 TFEU, apply to the Union's provision of humanitarian aid. The paper seeks to clarify what the obligations of 'coordination' and 'complementarity' entail. Finally, the paper considers the requirement that a European Voluntary Humanitarian Aid Corps is set up.

\section{Background}

In 2012, the European Commission's DirectorateGeneral for Humanitarian Aid and Civil Protection (DG ECHO) provided aid to third countries to the amount of approximately $€ 1,317$ million (Commission,

8 2013). This firmly placed the European Union (EU) among the world's largest humanitarian aid donors. Historically, the EU's humanitarian aid has been closely associated with its activities in the field of development cooperation. ${ }^{1}$ Initially, the EU had no overall scheme for the provision of humanitarian aid to third countries, and it founded such aid on a patchwork of legal bases. ${ }^{2}$ With the creation of the European Community Humanitarian

This article is based upon a paper that was presented at the 1st ReSHAPE Annual Workshop on 'The EU'S Emergency Policies' 2013, University of Catania (Italy), and subsequently, in a revised format, at the 3rd World Conference on Humanitarian Studies 2013, Kadir Has University, Istanbul (Turkey). The author is grateful for the constructive comments received at the two presentations. Moreover, the author gratefully acknowledges the assistance and/or suggestions for improvement provided by staff at the Danish Ministry of Foreign Affairs (Copenhagen) and at DG ECHO (Brussels), as well as by the editor Professor Arjen Boin and by three anonymous reviewers. It goes without saying that the usual disclaimer applies.
Office (ECHO) in 1992, a much more streamlined approach was adopted. ${ }^{3}$ The creation of DG ECHO led to a concentration of activities that previously had been carried out by several different Commission services, such as humanitarian assistance, emergency food aid, and prevention and disaster preparation activities (Khaliq, 2008; Van Elsuwege \& Orbie, 2014).

In 1996, the EU's Council of Ministers adopted Regulation 1257/96 concerning humanitarian aid. ${ }^{4}$ According to Article 1 of the Regulation, the objective of the EU's humanitarian assistance is:

to help people in third countries, particularly the most vulnerable among them, and as a priority those in developing countries, victims of natural disasters, man-made crises, such as wars and outbreaks of fighting, or exceptional situations or circumstances comparable to natural or man-made disasters ...

In accordance with its stated objective, the EU has since provided humanitarian assistance to a considerable number of people, primarily in developing countries but also to people in non-developing countries (Broberg, 2011).

The Humanitarian Aid Regulation found its legal basis in Article 179 of the EC Treaty's Title XX III on 'Development Cooperation'. ${ }^{6}$ However, humanitarian aid and 
development cooperation are fundamentally different and so it has been argued that this provision does not provide an adequate legal foundation for the Regulation and those activities which the EU carries out on this basis (cf. Broberg, 2011). If the Humanitarian Aid Regulation is based on an insufficient legal foundation, it may be held illegal by the Court of Justice of the EU. If the Court of Justice were to render such a ruling, it would throw the EU humanitarian aid scheme into disarray. ${ }^{7}$

In 2004, the EU Member States took steps towards remedying this problem by including Article III-321 in the proposed Constitutional Treaty, which was rejected by the French and the Dutch electorates in 2005. The Member States then drafted the Lisbon Treaty, which to a considerable extent was based upon the abandoned Constitutional Treaty. On 1 December 2009, the Lisbon Treaty went into force - and thereby introduced the Treaty on European Union (TEU) as well as the Treaty on the Functioning of the European Union (TFEU). The latter two treaties provide an explicit basis for the EU's actions in the field of humanitarian aid in Article 214 TFEU. $^{8}$

Until 2013, the EU had not used Article 214 TFEU to adopt a new legal framework for its provision of humanitarian aid. Regulation 1257/96 therefore continues to provide the legal framework in this respect. ${ }^{9}$ Nevertheless, it is useful to analyse how Article 214 TFEU may affect EU's humanitarian aid. This article therefore provides an analysis of a number of central aspects of this new important provision, focusing upon the likely consequences for the Union's humanitarian aid. It does so by taking a legal analytical approach, but also takes one step further than the classic so-called black-letter-law approach, thereby providing a more inclusive examination.

The article first considers the consequences regarding the competences and the procedures that have been laid down with regard to humanitarian aid following the entry into force of the Lisbon Treaty. It goes on to consider the general international legal principles that, according to Article 214 TFEU, apply to the Union's provision of humanitarian aid. Next, the article turns to consider the principles of 'coordination' and 'complementarity' - two principles that are intended to enhance efficiency of humanitarian aid measures and which are explicitly mentioned in Article 214 TFEU. Article 214(5) requires that a European Voluntary Humanitarian Aid Corps is set up, which is also considered in this article.

\section{Competences and procedures}

Even though the EU has provided humanitarian aid to third countries for half a century, it was only with the introduction of Article 214 TFEU that the Union has been given explicit competence in this field. This may seem surprising as the limits of the EU's competences are governed by the principle of conferral, which basically means that 'the Union shall act only within the limits of the competences conferred upon it by the Member States in the Treaties to attain the objectives set out therein. Competences not conferred upon the Union in the Treaties remain with the Member States'. ${ }^{10}$

The division of powers between the EU and its Member States may take one of three forms: the Union may have (1) exclusive competence vis-à-vis the Member States, (2) no competence vis-à-vis the Member States, or (3) shared competence with the Member States. Where competence is shared, both the EU and the Member States may legislate. However, when the Union has legislated with regard to a given matter over which there is shared competence, this pre-empts the Member States from legislating with regard to the same matter. ${ }^{11}$ However, a limited number of policy areas differ from this. Thus, when the Maastricht Treaty intro- 10 duced development cooperation into the EU's treaty system, it arguably provided for shared competence without pre-emption, i.e., parallel competences. ${ }^{12}$ This scheme of parallel competences has been codified in the Lisbon Treaty ${ }^{13}$ with regard to both development cooperation and humanitarian aid. ${ }^{14}$ Hence, Article 4(4) TFEU provides that:

In the areas of development cooperation and humanitarian aid, the Union shall have competence to carry out activities and conduct a common policy; however, the exercise of that competence shall not result in Member States being prevented from exercising theirs.

It follows that in the field of humanitarian aid, the EU and its Member States have shared competence without pre-emption. ${ }^{15}$ It is, however, important to observe that Article 214 TFEU in paragraph 6 lays down the principles of complementarity and coordination. It necessarily follows from these two principles that, even though both Member States and the EU can legislate over the same matter, they are nonetheless under an obligation of taking due account of each other when using their parallel legislative competences in this field. ${ }^{16}$ Moreover, when the Member States use their competence in the field of humanitarian aid, they are subject to the principle of loyalty vis-à-vis the EU. ${ }^{17}$

Article 214 TFEU only provides the EU with the legal basis for adopting legislation that lays down the framework (i.e., the procedures etc.) for providing humanitarian aid. ${ }^{18}$ In other words, in order to establish the specific rules for adopting decisions regarding the actual provision of humanitarian aid, it is necessary first to adopt legislation laying down how these decisions shall be adopted. This (framework) legislation must be adopted in accordance with the so-called ordinary leg- 
islative procedure, which essentially means that the European Commission must put forward a proposal whereupon both the Council of Ministers and the European Parliament must reach agreement. ${ }^{19}$ At the time of writing (2013), the EU has still not used the power laid down in Article 214 TFEU, which means that the Union's provision of humanitarian aid continues to be regulated by the 1996 Humanitarian Aid Council Regulation. $^{20}$

Article 214(1) TFEU also makes it clear that ' $[\mathrm{t}]$ he Union's operations in the field of humanitarian aid shall be conducted within the framework of the principles and objectives of the external action of the Union'.And that '[s]uch operations shall be intended to provide ad hoc assistance and relief and protection for people in third countries who are victims of natural or man-made disasters, in order to meet the humanitarian needs resulting from these different situations'. ${ }^{21}$ The objectives of the EU's external action have been laid down in Article 21 TEU, which provides that ' $[\mathrm{t}]$ he Union's action on the international scene shall be guided by the principles which have inspired its own creation, development and enlargement, and which it seeks to advance in the wider world: democracy, the rule of law, the universality and indivisibility of human rights and fundamental freedoms, respect for human dignity, the principles of equality and solidarity, and respect for the principles of the United Nations Charter and international law'. However, to a large extent, the pursuing of these objectives is hampered by the fact that under international humanitarian law, the sole lawful purpose of humanitarian aid is to relieve and prevent the suffering of victims of humanitarian crises.

Article 214(3) TFEU lays down that the EU is also competent to "conclude with third countries and competent international organisations' any agreement helping to achieve the humanitarian aid objectives referred to in paragraph 1 (of Article 214 TFEU) and in Article 21 of the TEU. The provision goes on to qualify this competence by stating that it must be 'without prejudice to Member States' competence to negotiate in international bodies and to conclude agreements'.

\section{General international legal humanitarian principles}

According to international humanitarian law, humanitarian aid must be based upon the following four legal principles:

- Humanity

- Neutrality

- Impartiality

- Independence

Indeed, in late 2007, when the Council, the European Parliament and the Commission adopted the so-called
European Consensus on Humanitarian Aid - a joint statement laying down a common vision that guides the action of the EU, both at its Member States and Union levels, in humanitarian aid in third countries - it was expressly stated that in its provision of humanitarian aid, the EU is 'firmly committed to upholding and promoting' these four 'fundamental humanitarian principles', and it goes on to define them in the following way:

'The principle of humanity means that human suffering must be addressed wherever it is found, with particular attention to the most vulnerable in the population. The dignity of all victims must be respected and protected'.

'Neutrality means that humanitarian aid must not favour any side in an armed conflict or other dispute'.

'Impartiality denotes that humanitarian aid must be provided solely on the basis of need, without discrimination between or within affected populations'.

'Respect for independence means the autonomy of humanitarian objectives from political, economic, military or other objectives, and serves to ensure that the sole purpose of humanitarian aid remains to relieve and prevent the suffering of victims of humanitarian crises'. 22

If we now turn to Article 214(2) TFEU, we find that the EU's '[h] umanitarian aid operations shall be conducted in compliance with the principles of international law and with the principles of impartiality, neutrality and non-discrimination'. This is a rather surprising statement because it includes only two of the four 'fundamental humanitarian principles'; on the face of it, the principles of humanity and independence have been left out. The unavoidable question is why these two principles are not included, and what substantive impact (if any) this exclusion may have? To answer this question, we must take a brief look at the history behind the Lisbon Treaty.

In 2004, the EU tried to replace its former treaty basis by a Constitutional Treaty. In Article III-321, the Constitutional Treaty contained a provision on humanitarian aid whose paragraph 2 is identical to paragraph 2 of Article 214 TFEU, so that neither of these two provisions expressly includes humanity and independence among the principles that shall be observed. According to people who were close to the negotiations of this provision of the Constitutional Treaty, the exclusion of two of the four humanitarian principles was in no way intentional. Rather, it was a simple oversight at a very early stage in the negotiations. Before the negotiations were completed, the Commission drew attention to this oversight, but this happened at such a late stage that the chairmanship considered it to be too problematic to reopen the negotiations. In support of the refusal to reopen negotiations, it was observed that general principles of international law were covered by the draft treaty so that it would merely be a reiteration to 
explicitly refer to the principles in the provision. ${ }^{23}$ With particular regard to 'humanity', the view was that this principle was so obvious that in any event it would be superfluous to mention it. In contrast, some viewed 'independence' to conflict with the political foundation of the European Commission and with the objective that the EU should have a 'comprehensive approach' in its external relations. ${ }^{24}$

After the Dutch and the French electorate rejected the Constitutional Treaty, the EU Member States decided instead to create a less ambitious new treaty basis. The Lisbon Treaty was closely modelled upon the Constitutional Treaty - and this was also true with regard to Article 214 TFEU on humanitarian aid. The Lisbon Treaty was signed in late 2007 , but it only entered into force towards the end of 2009. Simultaneously, the European Consensus on Humanitarian Aid was drafted and it was subsequently approved in 2007. During negotiations on the Lisbon Treaty, the Commission again tried to reopen discussions on the inclusion of all four fundamental humanitarian principles. Again, this was declined out of fear that it would open a Pandora's Box. Moreover, a supplementary argument against reopening the negotiations was voiced this time, namely that all four principles were listed in the European Consensus on Humanitarian Aid.

Irrespective of whether the exclusion of the principles of 'humanity' and 'independence' is or is not an oversight, it does not necessarily have any appreciable ramifications. Thus, Article 214(1) TFEU expressly lays down that ' $[\mathrm{t}]$ he Union's operations in the field of humanitarian aid ... shall be intended to provide ad hoc assistance and relief and protection for people in third countries who are victims of natural or man-made disasters, in order to meet the humanitarian needs resulting from these different situations'. While perhaps this statement does not completely qualify as a paraphrasing of the principle of humanity, arguably it comes very close. ${ }^{25}$ In contrast, Article 214 TFEU's express reference to non-discrimination cannot be viewed as a paraphrase of the principle of independence. ${ }^{26}$ And the apparent non-inclusion of the principle of independence is particularly problematic as Article 214(1) TFEU requires that ' $[t]$ he Union's operations in the field of humanitarian aid shall be conducted within the framework of the principles and objectives of the external action of the Union'. On the face of it, this requirement would seem to conflict directly with the very essence of the principle of independence. ${ }^{27}$

Nonetheless, Article 214(2) TFEU provides that the Union's humanitarian aid operations must be conducted in compliance with the principles of international law'. And all the above four principles - including also the principle of humanity and the principle of independence - form part of international humanitarian law. ${ }^{28}$ Put differently, even if there had been no express reference to any of the four fundamental principles in Article 214 TFEU, the Union would still be bound by these as they are all covered by the reference to 'international law'. ${ }^{29}$

To complete the picture, we may observe that the European Commission apparently also takes the view that all four general principles continue to apply to the Union's provision of humanitarian aid. Hence, in the 2012 Proposal for a Regulation of the European Parliament and of the Council Establishing the European Voluntary Humanitarian Aid Corps - EU Aid Volunteers, the Commission (inter alia) in recital 3 and Article 4(1) expressly refers to all four 'fundamental humanitarian principles' ${ }^{30}$

\section{Coordination and complementarity}

The Maastricht Treaty (1992) introduced a specific 'title' on the EU's policy on 'development cooperation' into the EC Treaty (Title XX). Central features of this new title were the principles of coherence, of complementarity, and of coordination; collectively referred to as the three Cs.

'Coherence' means that different Union policies shall not counteract one another. While after the entry into force of the Lisbon Treaty, we still find this principle in Article 208(1)(2) TFEU regarding the EU's development cooperation policy, ${ }^{31}$ the principle has not been included in Article 214 TFEU. ${ }^{32}$ This can only partly be explained by the principle of independence. Admittedly, the coherence principle entails that humanitarian aid cannot be used to further other policies of the donor, but the principle of independence does not prohibit a donor from taking due account of its humanitarian aid obligations in the other policies pursued by the donor. The reason why Article 214 TFEU does not impose on the EU a duty of making the Union's other policies coherent with its humanitarian aid policy is not clear; perhaps the drafters of the Lisbon Treaty simply found it difficult to conceive of any real clashes between the EU's other policies and its policy on humanitarian aid, as the latter is exclusively intended to '... provide ad hoc assistance and relief and protection for people in third countries who are victims of natural or man-made disasters, in order to meet the humanitarian needs resulting from these different situations' ${ }^{33}$

While coherence, the first of the three Cs, has not been made part of Article 214 TFEU, we do find the other two Cs therein: complementarity and coordination.

With regard to complementarity,Article 214(1) TFEU provides that ' $\mathrm{t}]$ he Union's measures and those of the Member States shall complement and reinforce each other'. In Article 214(6) TFEU, reference is again made to 'complementarity'. This essentially means that both Member States and the EU (in practice the Commission) must take note of the (existing as well as 
proposed) humanitarian aid activities of the other parties so as to avoid overlapping activities where this will make the aid less efficient. ${ }^{34}$ In this regard, it may be recalled that Member States and the Union hold parallel competences so that legislation by one does not preempt the others' ability to legislate in the same field. This increases the risk of overlapping activities - and thus strengthens the need for a delimitation measure between the two sides. The principle of complementarity meets this need.

The TFEU lays down the complementarity principle with regard to not only humanitarian aid, but also the development cooperation policy. Article 208(1)(1) TFEU provides that ' $[t]$ he Union's development cooperation policy and that of the Member States complement and reinforce each other'.While Article 214 TFEU on humanitarian aid was only introduced with the Lisbon Treaty, Article 208 TFEU on development cooperation was originally introduced with the 1992 Maastricht Treaty. However, prior to the Lisbon Treaty, the provision stated that '[EU] policy in the sphere of development cooperation [...] shall be complementary to the policies pursued by the Member States'. ${ }^{35}$ As will be clear from the two quotations, the principle of complementarity in the field of development cooperation was changed from (prior to the Lisbon Treaty) making the Union's policy subordinate to those of the Member States to (after the Lisbon Treaty) placing the Union's and its Member States' policies on an even footing. As the post-Lisbon provisions in Articles 208(1)(2) and 214(1) TFEU, respectively are both cut from the same cloth, it seems only natural that the EU and its Member States must also be placed on an equal footing when it comes to humanitarian aid. In other words, complementarity must be mutual.

Article 214(6) TFEU specifies that ' $[t]$ he Commission may take any useful initiative to promote coordination between actions of the Union and those of the Member States, in order to enhance the efficiency and complementarity of Union and national humanitarian aid measures'. It is clear from this provision that 'coordination' shall enhance 'efficiency' as well as 'complementarity', and that the coordination must be made between 'actions'. Hence, it appears that 'coordination' is primarily about the different actors taking active steps towards 'talking together'. ${ }^{36}$ In other words, based upon the principle of coordination, Article 214(6) TFEU empowers the Commission to take steps to promote coordination between the EU and its Member States so that they may actively work towards improving the effectiveness of their efforts in the field of humanitarian aid. ${ }^{37}$

The principle of coordination applies not only to the EU's relationship with its Member States, but also to the Union's relationship with international organizations and bodies - including not least the United Nations system. ${ }^{38}$ In this regard, the duty of coordination is unilaterally placed on the EU.

Perhaps somewhat surprisingly, Article 214 TFEU does not explicitly oblige the EU and its Member States to apply the principle of coordination towards other actors - such as other donors (that are neither Member States nor international organizations and bodies) or recipient countries. Such a duty, however, seems to follow from (existing) secondary soft-law measures. ${ }^{39}$

\section{A European Voluntary Humanitarian Aid Corps}

Paragraph 5 of Article 214 TFEU provides that a European Voluntary Humanitarian Aid Corps shall be set up. To this end, the European Parliament and the Council shall adopt a regulation laying down the rules and procedures for the operation of the Corps - and hereby establish 'a framework for joint contributions from young Europeans' to the EU's humanitarian aid operations.

It might seem somewhat odd that Article 214 TFEU provides for a European 'Aid Corps'; arguably, the idea of the creation of such corps does not sit well with the rest of Article 214 TFEU. The idea was originally tabled by then Greek minister for foreign affairs George Papandreou during the negotiations for a Constitutional Treaty. When the Constitutional Treaty was abandoned only to be 'replaced' by the Lisbon Treaty, the provision was carried over into the latter Treaty.

The introduction of a European 'Aid Corps' was intended to further ordinary citizens' identification with the 'European Project'. It was inspired by the American 'Peace Corps' which, however, has primarily a development objective, whereas the European Voluntary Humanitarian Aid Corps has a humanitarian one. Indeed, the European Commission found that it would be inexpedient to send young European volunteers to what often would be high-risk crisis operations. It therefore worked to have the provision moved to the Constitutional Treaty's chapter on development cooperation or, alternatively, to introduce a new provision on voluntary work in the part of that Treaty that addressed citizenship. However, at the time when the Commission put forward these proposals, the Greek proposal had found widespread support in the Convention that was to draft the Constitutional Treaty - and it therefore became part of that treaty's provision on humanitarian aid - and was subsequently transferred to the Lisbon Treaty.

In 2010, the Commission (2010) published a communication titled 'How to express EU citizen's solidarity through volunteering: First reflections on a European Voluntary Humanitarian Aid Corps'. In this document, the Commission provides information on the then EU 
current situation of the use of humanitarian aid volunteers, lays down the framework, and points to the way forward. In 2012, the Commission tabled a 'Proposal for a Regulation of the European Parliament and of the Council Establishing the European Voluntary Humanitarian Aid Corps EU Aid Volunteers'.

Although the regulation has not yet been adopted by the Council and the European Parliament, the Commission has made it rather clear that the intentions are to develop a global initiative whereby an expected 10,000 people will be able to volunteer to take part in humanitarian operations in the period 2014-2020. A central objective of the initiative is to bring volunteers and organizations from different countries to work together in common projects. In this regard, it is of particular relevance that the European Commission has found that a major drawback regarding the use of volunteer workers is that some volunteers - while having the best intentions - are ineffective and in some cases even disruptive. To counter this, the Commission proposes to develop European standards in the field in order to provide a quality label denoting proper training for volunteers and thereby ensure a positive impact of humanitarian aid. Hereby, 'trained volunteers will be deployed as EU Aid Volunteers in humanitarian projects worldwide and a network of EU Aid Volunteers will be created, so they can interact with and support each other before, during, and after deployment. Other people can also get involved through online volunteering, supporting volunteers already in the field or helping humanitarian organizations with tasks that can be done from home on a computer' (DG ECHO, 2014).

The Commission's proposal is to certify humanitarian organizations that adhere to the European standards of managing humanitarian volunteers. The certified organizations will, in turn, identify suitable humanitarian projects and may thereupon apply for EU grants to deploy EU Aid Volunteers. The proposal includes a budget of €147.9 million for 2014-2020 that will be used for (1) an extensive training package, (2) deployment, (3) capacity building in communities hit by disasters, and (4) supporting activities (ECHO, 2014).

The European Voluntary Humanitarian Aid Corps has been subject to criticism - in particular from the non-governmental organization (NGO) community. According to Van Elsuwege and Orbie (2014), 'the NGO community fears that [the creation of the European Voluntary Humanitarian Aid Corps] may undermine the increasing professionalism in the humanitarian aid sector potentially leading to dangerous situations in conflict areas. In general, there is a feeling that this initiative may be used as a promotional tool to increase the visibility of the EU's humanitarian actions. [...] Such visibility requirements may conflict with the humanitarian imperative to provide aid on a needs-based approach. Moreover, it may affect the independence from political, economic, military or other objectives'.

\section{Conclusion}

This article has examined most, but not all, parts of Article 214 TFEU which provides the new treaty basis for EU humanitarian aid. We first considered the division of powers between the EU and its Member States in this field. As a clear main rule under EU law, the division of competence may take the forms of (1) exclusive Union competence vis-à-vis the Member States, (2) no Union competence vis-à-vis the Member States, or (3) shared competence between the Union and the Member States in combination with pre-emption where the Union uses its competence. Humanitarian aid, however, constitutes an exception to the normal scheme, as the Union and its Member States have shared competence without pre-emption, also referred to as parallel competences.

Article 214 TFEU gives the Union competence to adopt a new regulation on humanitarian aid to provide the legal framework for the provision of humanitarian aid. So far the Union has not used this competence, which means that its secondary legislation on humanitarian aid continues to be found in the 1996 Humanitarian Aid Council Regulation.

We next went on to consider to what general international legal humanitarian principles Article 214 TFEU refers. In this respect, it is pointed out that the provision only lists the two first-mentioned of the following four legal principles that are normally invoked in this respect: (1) neutrality, (2) impartiality (3) humanity, and (4) independence. Hence, there is no express reference either to the principle of humanity, or to the principle of independence. While it is acknowledged that the lack of an express reference to these two principles is rather surprising, it is simultaneously argued that no substantive consequences are likely to flow therefrom. This is so as Article 214 TFEU also includes a reference to the principles of international law, which in any event covers all four legal principles.

We thereupon turned to the principles of 'complementarity' and 'coordination'. The EU's development cooperation policy is, inter alia, founded on the principles of coherence, complementarity, and coordination. Article 214 TFEU has taken over two of these three principles, namely those of complementarity and coordination. In defining their content, we drew on the meanings that have been given to these principles within the Union's development cooperation policy.

Finally, it is observed that Article 214 TFEU obliges the EU to create a European Voluntary Humanitarian Aid Corps. To this end, in 2012, the Commission tabled a 'Proposal for a Regulation of the European Parliament 
and of the Council Establishing the European Voluntary Humanitarian Aid Corps EU Aid Volunteers'. If adopted, this regulation will lay down the rules and procedures for the operation of the Corps - and hereby establish a framework for joint contributions from young Europeans to the EU's humanitarian aid operations.

\section{Notes}

1. See in this respect Hoebink (2005, pp. 130, 135, 148).

2. The legal bases included the Lomé (and Yaoundé) Conventions with regard to assistance to the so-called ACP countries (i.e., certain African, Caribbean, and Pacific countries) and they included framework regulations and the general budget procedure.

3. As noted, ECHO originally stood for European Community Humanitarian Aid Office. In 2004, it became the Directorate-General for Humanitarian Aid before integrating Civil Protection in 2010. Formally speaking, its present name is Directorate-General for Humanitarian Aid and Civil Protection, but in practice references are widely made to 'ECHO' or 'DG ECHO'.

4. In what follows, Regulation $1257 / 96$ will be referred to as the 'Humanitarian Aid Regulation' or simply the 'Regulation'.

5. It may be observed in passing that by stating that developing countries shall be given priority, the Humanitarian Aid Regulation arguably presupposes that the EU is not under an indispensable obligation to provide humanitarian assistance to non-developing countries.

6. Today, this provision corresponds to Article 209 TFEU.

7. It is difficult to provide any firm assessment of the likelihood of such case being brought - but presumably the likelihood is limited.

8. Humanitarian and rescue tasks are also mentioned in Article 43(1) TEU in the context of the Union's common security and defence policy. The present paper focuses only on Article 214 TFEU.

9. This essentially means that also those problems that have been identified with regard to Regulation $1257 / 96$ persist.

10. Article 5(1) and (2) TEU. For a discussion of this matter, see Broberg (2011).

11. Article 2(2) TFEU.

12. This was not least clear from the requirement that $E U$ development cooperation policy should complement the development policies of its Member States, cf.Article 177 of the EC Treaty. See further the treatment of the complementarity and the coordination requirements in this article. See also Council (2002a, pp. 8-9). Note in this regard that Working Group $V$ expressly observed that the classification of, among others, the Union's competence in the field of development cooperation should be made 'without changing the legal competence of the Union in the areas concerned'. In other words, Working Group V also took the view that development cooperation was an area of shared competence without pre-emption.

13. See further Craig (2010, pp. 170-1, 392-393), Kaddous (2009, p. 185), and Pernice (2003, p. 30).
14. Prior to the Lisbon Treaty, the principal legal basis for the EU's provision of humanitarian aid was Article 179 of the EC Treaty - which today corresponds to Article 209 TFEU - providing for the adoption of 'measures necessary for the implementation of development cooperation policy'.

15. Sometimes referred to as 'parallel competence'. Stefanellia and Williams (2011, pp. 56-7) qualify the competence as simply 'shared'.

16. See further below section 4 .

17. The principle of loyalty is laid down in Article 4(3) TEU. See also Amato and Ziller (2007, p. 292).

18. This construction means that it will be possible to retain the system that has been established under the present Humanitarian Aid Regulation which enables the Commission to react very swiftly also where the need for humanitarian aid arises very suddenly and unexpectedly. See also Council (2002b).

19. See Article 294 TFEU.

20. Regulation $1257 / 96$.

21. See also Article 43(1) TEU.

22. European Consensus on Humanitarian Aid, paragraphs 10-14. Van Elsuwege and Orbie (2014) take the view that 'The notion of independence ... may be considered as a "derived principle" insofar as its substance, i.e., the autonomy of humanitarian objectives from political, military or economic influences, follows from the other principles'. The present author takes the view that there may be situations where the principle of independence is more than merely a 'derived principle'.

23. Indeed,Working Group VII which provided the draft for, inter alia, the Constitutional Treaty's provision on humanitarian aid made explicit reference to both the principle of humanity and the principle of independence in the following terms: 'The Group further noted the specific nature of humanitarian aid, on which the principles of independence and impartiality applied, not only because of international obligations but also to ensure that aid is delivered effectively and without additional risks to the lives of the providers' (Council, 2002c).

24. Information provided in personal communication between the author and Commission officials.

25. See also Article 1 of the European Union's Charter on Fundamental Rights which provides that '[h]uman dignity is inviolable. It must be respected and protected'.

26. According to Cremona (2003, p. 1364), the principle of non-discrimination 'in particular will reinforce the Union's current policy of continuing to provide humanitarian aid to the peoples of countries whose governments are the subject of sanctions or negative conditionality'.

27. On this requirement, see also below section 4, regarding the principle of coherence.

28. Indeed, this has also been expressly established in the European 'Consensus on Humanitarian Aid' which in paragraph 3 provides that the four principles are all 'enshrined in International Law, in particular International Humanitarian Law'. See likewise Casolari (2012, p. 152).

29. For a rather similar view, see Van Elsuwege and Orbie (2014) and Casolari (2012, p. 152). 
30. See likewise DG ECHO (2012).

31. The principle of policy coherence for development sometimes simply called PCD - is termed as follows: 'The Union shall take account of the objectives of development cooperation in the policies that it implements which are likely to affect developing countries'.

32. But see the European Consensus on Humanitarian Aid paragraph 30, which refers to 'policy coherence', and paragraph 84, which refers to 'coherence in Community policies'. According to Van Elsuwege and Orbie (2014), the requirement in Article 214(1) that '[t]he Union's operations in the field of humanitarian aid shall be conducted within the framework of the principles and objectives of the external action of the Union' may be construed as an obligation to pursue coherence. In the present author's view, such construction would seem to imply that the EU's humanitarian aid policy must adapt to other external Union policies, whereas it is not equally obvious that other external Union policies shall adapt to the Union's humanitarian aid policy. It is respectfully submitted that this is likely to contravene the principle of independence.

33. Cf. Article 214(1). See also European Consensus on Humanitarian Aid, paragraphs 30 and 93. In any event, the Lisbon Treaty in Article 7 TFEU has introduced an allencompassing principle of policy coherence - thus also covering the Union's policy with regard to humanitarian aid.

34. Christiansen (2012, p. 246) observes that 'European responses to international crises - the 2010 earthquake in Haiti, the 2011 nuclear disaster in Fukushima and the 2011 Libya conflict - all demonstrated the continuing differences among the Member States rather than the unity of the EU'. While Thomas Christiansen comments on the new institutional arrangement following the Lisbon Treaty and not on the provisions in Article 214 TFEU, the quote illustrates the need for coordination and complementarity.

35. Article 177(1) of the EC Treaty.

36. In contrast, 'complementarity' is the (positive) outcome of successful coordination.

37. Arguably, the Commission's competence to coordinate humanitarian aid sits somewhat uncomfortably with the fact that the Union and its Member States have parallel competences in the field of humanitarian aid.Thus, Craig (2010, p. 395) observes that the Lisbon Treaty has left open 'the precise scope of the EU's competence in this area'. And he particularly refers to Article 214(6) TFEU and the fact that this provision enables 'the Commission to take initiatives to promote coordination between EU and Member State actions, in order to enhance the efficiency and complementarity of their respective aid measures'.

38. Article 214(7) TFEU.

39. See European Consensus on Humanitarian Aid, paragraphs 70 and 87 .

\section{References}

Amato, G. and Ziller, J. (2007), The European Constitution: Cases and Materials in EU and Member States' Law, Edward Elgar, Cheltenham, UK.

Broberg, M. (2011), 'Legal Basis of EU Council Regulation 1257/96 Concerning Humanitarian Aid - Time for Revision?', in Heintze, H.J. and Zwitter, A. (eds), International Law and Humanitarian Assistance - A Crosscut Through Legal Issues Pertaining to Humanitarianism, Springer, London, pp. ••-•••.

Casolari, F. (2012), 'The External Dimension of the EU Disaster Response', in De Guttry, A., Gestri, M. and Venturini, G. (eds), International Disaster Response Law, T.M.C. Asser Press, The Hague, pp. ••-••.

Christiansen, T. (2012), 'The European Union after the Lisbon Treaty: An Elusive 'Institutional Balance', in Biondi, A., Eeckhout, P. and Ripley, S. (eds), EU Law After Lisbon, Oxford University Press, Oxford, pp. ••-••.

Commission (2010), Communication from the Commission to the European Parliament and the Council, 'How to express EU citizen's solidarity through volunteering: First reflections on a European Voluntary Humanitarian Aid Corps', Brussels: 23 November 2012, Reference No. COM(2010) 683 final.

Commission (2012), Proposal for a Regulation of the European Parliament and of the Council, 'Establishing the European Voluntary Humanitarian Aid Corps', Brussels: 19 September 2012, Reference No. COM/2012/514 final.

Commission (2013), Report from the Commission to the European Parliament and the Council, 'Annual Report on the European Union's Humanitarian Aid and Civil Protection Policies and their Implementation in 2012', Reference No. $\operatorname{COM}(2013) 658$ final.

Council (1996), Council Regulation No. $1257 / 96$ of 20 June 1996 concerning 17 humanitarian aid.

Council (2002a), 'Final report of Working Group V', The European Convention, Brussels: 4 November 2002, Reference No. CONV 375/1/02, http://europeanconvention.eu.int/pdf/reg/en/02/cv00/cv00375-re01.en02.pdf (accessed ••).

Council (2002b), 'Working Group VII - External Action', Brussels: 21 November 2002, Reference No. working document 48, http://european-convention .eu.int/docs/wd7/5441.pdf (accessed ••)

Council (2002c), 'Final report of Working Group VII on External Action', Brussels: 16 December 2002, Reference No. CONV 459/02.

Council (2008), European Consensus on Humanitarian Aid, Reference No. 2 2008/C 25/01.

Craig, P. (2010), The Lisbon Treaty - Law, Politics, and Treaty Reform, Oxford University Press, Oxford.

Cremona, M. (2003), 'The Draft Constitutional Treaty: External Relations and External Action', Common Market Law Review, Volume 40, Number 6, pp. $1347-1366$.

DG ECHO (2012), 'Presentation', http://ec.europa.eu/echo/about/presentation en.htm (accessed $\bullet \bullet)$

DG ECHO (2014), 'EU Aid Volunteers: Commission Proposes New Global Humanitarian Initiative', http://ec.europa.eu/echo/euaidvolunteers/index en.htm (accessed $\bullet \cdot$ )

ECHO (2014), 'Fact Sheet - EU Aid Volunteers', http://ec.europa.eu/echo/files/ aid/countries/factsheets/thematic/euaidvolunteers en.pdf (accessed $\bullet \bullet$ ).

Hoebink, P. (2005), 'European Development Aid in Transition', in Babarinde, O. and Faber, G. (eds), The European Union and the Developing Countries - The Cotonou Agreement, Martinus Nijhoff Publishers, Leiden, pp. ••_.•.

Kaddous, C. (2009), 'External Action under the Lisbon Treaty', in Pernice, I. and Tanchev, E. (eds), Ceci n'est pas une Constitution - Constitutionalisation without a Constitution?, Baden-Baden, Nomos, pp. ••-•••.

Khaliq, U. (2008), Ethical Dimensions of the Foreign Policy of the European Union: A Legal Appraisal, Cambridge University Press, Cambridge, pp. ••-.•.

Pernice, I. (2003), 'Elements and Structures of the European Constitution', in Pernice, I. and Miccù, R. (eds), The European Constitution in the Making, Nomos, Baden-Baden, pp. $\bullet-\bullet \cdot$

Stefanellia, J.N. and Williams, S. (2011), 'Disaster Strikes: Regulatory Barriers to the Effective Delivery of International Disaster Assistance within the EU', International Humanitarian Legal Studies, Volume 2, Number 1, pp. 53-83.

Van Elsuwege, P. and Orbie, J. (2014), 'The EU's Humanitarian Aid Policy after Lisbon: Implications of a New Treaty Basis', in Govaere, I. and Poli, S. (eds), Management of Global Emergencies, Threats and Crises by the European Union, Brill/Nijhoff, $\bullet \cdot$, pp. $\bullet \cdot-\bullet$. 


\section{AUTHOR QUERY FORM}

Dear Author,

During the preparation of your manuscript for publication, the questions listed below have arisen. Please attend to these matters and return this form with your proof.

Many thanks for your assistance.

\begin{tabular}{|c|c|c|}
\hline $\begin{array}{l}\text { Query } \\
\text { References }\end{array}$ & Query & Remarks \\
\hline 1 & $\begin{array}{l}\text { AUTHOR: A short title running head was not supplied; please check if this one is suitable } \\
\text { and, if not, please supply a short title that can be used instead. }\end{array}$ & \\
\hline 2 & WILEY BLACKWELL: Please supply the article type for this article. & \\
\hline 3 & AUTHOR: Please confirm if the article title is correct. & \\
\hline 4 & $\begin{array}{l}\text { AUTHOR: Please check and confirm that the affiliation address for author Morten Broberg is } \\
\text { correct. }\end{array}$ & \\
\hline 5 & AUTHOR: Please supply the e-mail address for the author. & \\
\hline 6 & $\begin{array}{l}\text { AUTHOR: Please check and confirm that the term 'third countries' throughout the text is } \\
\text { correct, or should it be changed to 'third world countries'? }\end{array}$ & \\
\hline 7 & $\begin{array}{l}\text { AUTHOR: Is TFEU an abbreviation that needs to be spelled out during first mention? If so, } \\
\text { please supply its full form. }\end{array}$ & \\
\hline 8 & $\begin{array}{l}\text { AUTHOR: European Union. Is this the correct full form for EU? Please change if it is } \\
\text { incorrect. }\end{array}$ & \\
\hline 9 & $\begin{array}{l}\text { AUTHOR: Is EC an abbreviation that needs to be spelled out during first mention? If so, } \\
\text { please supply its full form. }\end{array}$ & \\
\hline 10 & $\begin{array}{l}\text { AUTHOR: 'However. . this.' This sentence has been modified for clarity. Please check and } \\
\text { confirm if this is correct. }\end{array}$ & \\
\hline 11 & $\begin{array}{l}\text { AUTHOR: 'Central. . Cs.' This sentence has been modified for clarity. Please check and } \\
\text { confirm if this is correct. }\end{array}$ & \\
\hline 12 & $\begin{array}{l}\text { AUTHOR: non-governmental organization. Is this the correct full form for NGO? Please } \\
\text { change if it is incorrect. }\end{array}$ & \\
\hline 13 & AUTHOR: Please supply page range for Reference Broberg, 2011. & \\
\hline 14 & AUTHOR: Please supply the page range for Reference Casolari, 2012. & \\
\hline 15 & AUTHOR: Please supply page range for Reference Christiansen, 2012. & \\
\hline 16 & $\begin{array}{l}\text { AUTHOR: Reference Commission } 2012 \text { has not been cited in the text. Please indicate where } \\
\text { it should be cited or delete it from reference list. }\end{array}$ & \\
\hline 17 & $\begin{array}{l}\text { AUTHOR: Reference Council } 1996 \text { has not been cited in the text. Please indicate where it } \\
\text { should be cited or delete it from reference list. }\end{array}$ & \\
\hline 18 & $\begin{array}{l}\text { AUTHOR: Please check this website address/URL and confirm that it is correct. (Please note } \\
\text { that it is the responsibility of the author(s) to ensure that all URLs given in this article are } \\
\text { correct and useable.) }\end{array}$ & \\
\hline 19 & AUTHOR: Please supply accessed date for Reference Council, 2002a. & \\
\hline 20 & AUTHOR: Please supply accessed date for Reference Council, 2002b. & \\
\hline 21 & $\begin{array}{l}\text { AUTHOR: Reference Council } 2008 \text { has not been cited in the text. Please indicate where it } \\
\text { should be cited or delete it from reference list. }\end{array}$ & \\
\hline 22 & AUTHOR: Please supply accessed date for Reference DG ECHO, 2012. & \\
\hline 23 & AUTHOR: Please supply accessed date for Reference DG ECHO, 2014. & \\
\hline
\end{tabular}




\begin{tabular}{|l|l|l|}
\hline $\begin{array}{l}\text { Query } \\
\text { References }\end{array}$ & Query & Remarks \\
\hline 24 & AUTHOR: Please supply accessed date for Reference ECHO, 2014. & \\
\hline 25 & AUTHOR: Please supply page range for Reference Hoebink, 2005. & \\
\hline 26 & AUTHOR: Please supply page range for Reference Kaddous, 2009. & \\
\hline 27 & AUTHOR: Please supply page range for Reference Khaliq, 2008. & \\
\hline 28 & AUTHOR: Please supply page range for Reference Pernice, 2003. & \\
\hline 29 & $\begin{array}{l}\text { AUTHOR: Please supply the city location of publisher and page range for Reference Van } \\
\text { Elsuwege \& Orbie, 2014. }\end{array}$ & \\
\hline
\end{tabular}


Required software to e-Annotate PDFs: Adobe Acrobat Professional or Adobe Reader (version 8.0 or above). (Note that this document uses screenshots from Adobe Reader $\mathrm{X}$ )

The latest version of Acrobat Reader can be downloaded for free at: http://get.adobe.com/reader/

Once you have Acrobat Reader open on your computer, click on the Comment tab at the right of the toolbar:

닙

This will open up a panel down the right side of the document. The majority of tools you will use for annotating your proof will be in the Annotations section, pictured opposite. We've picked out some of these tools below:

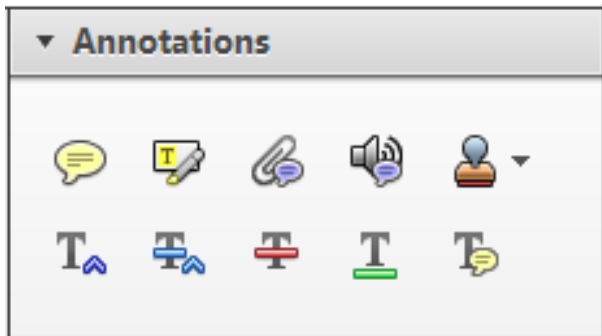

1. Replace (Ins) Tool - for replacing text.

Strikes a line through text and opens up a text box where replacement text can be entered.

\section{How to use it}

- Highlight a word or sentence.

- Click on the Replace (Ins) icon in the Annotations section.

- Type the replacement text into the blue box that appears.

Idard tramework for the analysis of $\mathrm{m}$ icy-Nevertheless, it also led to exog،

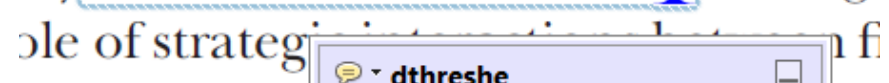
aber of comp 08/06/2011 15:58:17

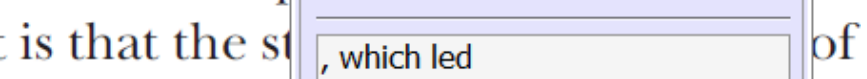
nain compo: be level, are exc nc

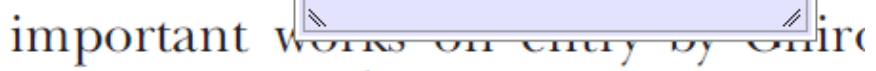
M heneferth) ${ }^{1}$ we anen the 'hlark $\mathrm{h}$

3. Add note to text Tool - for highlighting a section to be changed to bold or italic.

T Highlights text in yellow and opens up a text box where comments can be entered.

\section{How to use it}

- Highlight the relevant section of text.

- Click on the Add note to text icon in the Annotations section.

- Type instruction on what should be changed regarding the text into the yellow box that annears.

namic responses of mark ups ent with the VAR evidence

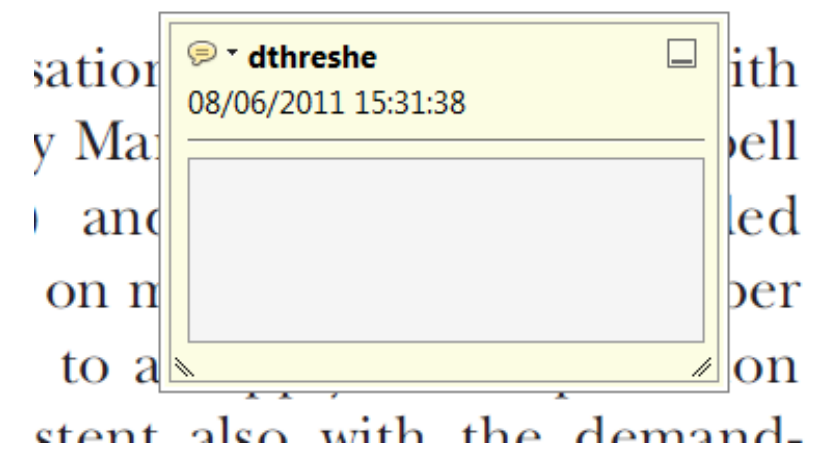

2. Strikethrough (Del) Tool - for deleting text.

Thikes a red line through text that is to be deleted.

\section{How to use it}

- Highlight a word or sentence.

- Click on the Strikethrough (Del) icon in the Annotations section.

there is no room tor extra prohts al c ups are zero and the number of ret) values are not determined by Blanchard and Kiyotaki (1987), rfect competition in general equilil ts of aggregate demand and supply lassical framework assuming monol eon an evorenois number of firms

\section{Add sticky note Tool - for making notes at} specific points in the text.

Marks a point in the proof where a comment needs to be highlighted.

\section{How to use it}

- Click on the Add sticky note icon in the Annotations section.

- Click at the point in the proof where the comment should be inserted.

- Type the comment into the yellow box that appears.

lallu allu suppiy silucks. hivst vi

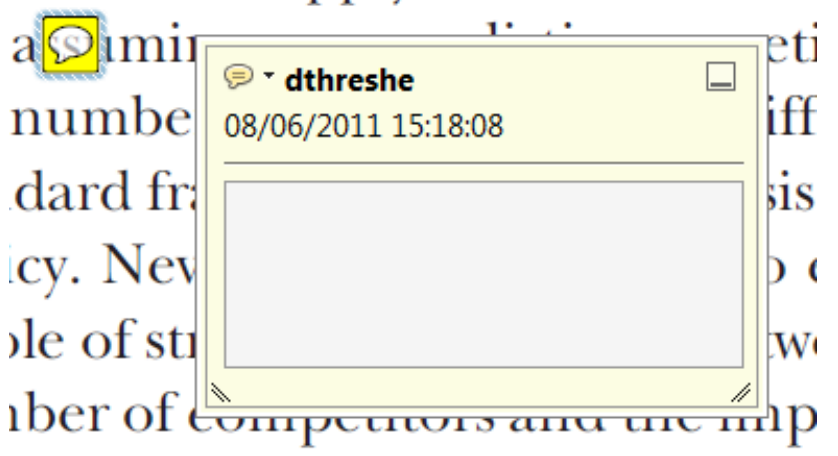

is that the structure of the secto 
5. Attach File Tool - for inserting large amounts of text or replacement figures.

Inserts an icon linking to the attached file in the appropriate pace in the text.

How to use it

- Click on the Attach File icon in the Annotations section.

- Click on the proof to where you'd like the attached file to be linked.

- Select the file to be attached from your computer or network.

- Select the colour and type of icon that will appear in the proof. Click OK.

E N D

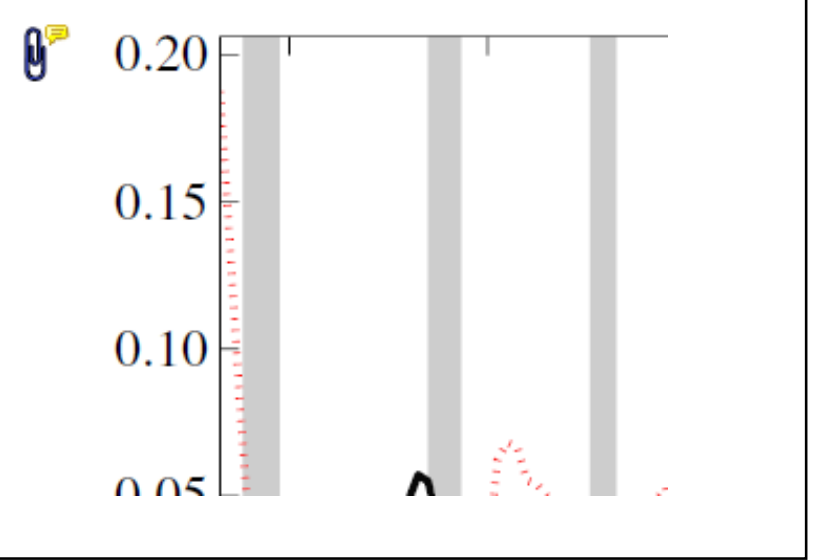

6. Add stamp Tool - for approving a proof if no corrections are required.

- Inserts a selected stamp onto an appropriate place in the proof

\section{How to use it}

- $\quad$ Click on the Add stamp icon in the Annotations section.

- $\quad$ Select the stamp you want to use. (The Approved stamp is usually available directly in the menu that appears).

- Click on the proof where you'd like the stamp to appear. (Where a proof is to be approved as it is, this would normally be on the first page).

of the Dusiness cycie, starting with the on perfect competition, constant ret

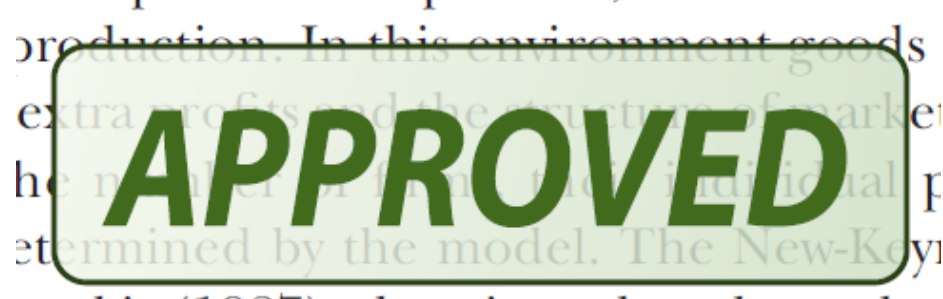

otaki (1987), has introduced produc general equilibrium models with nomin
- Drawing Markups

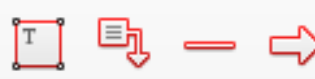

$0 \square \sqrt{6} D$

\section{How to use it}

- Click on one of the shapes in the Drawing Markups section.

- Click on the proof at the relevant point and draw the selected shape with the cursor.

- To add a comment to the drawn shape, move the cursor over the shape until an arrowhead appears.

- Double click on the shape and type any text in the red box that appears.
7. Drawing Markups Tools - for drawing shapes, lines and freeform annotations on proofs and commenting on these marks.

Allows shapes, lines and freeform annotations to be drawn on proofs and for comment to be made on these marks.

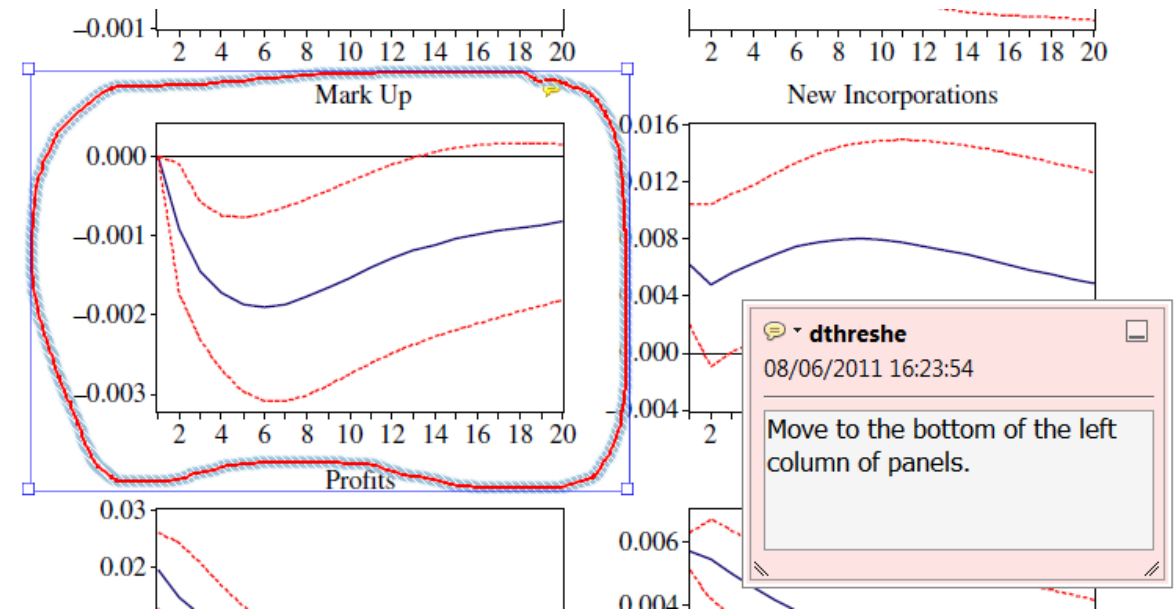

For further information on how to annotate proofs, click on the Help menu to reveal a list of further options:

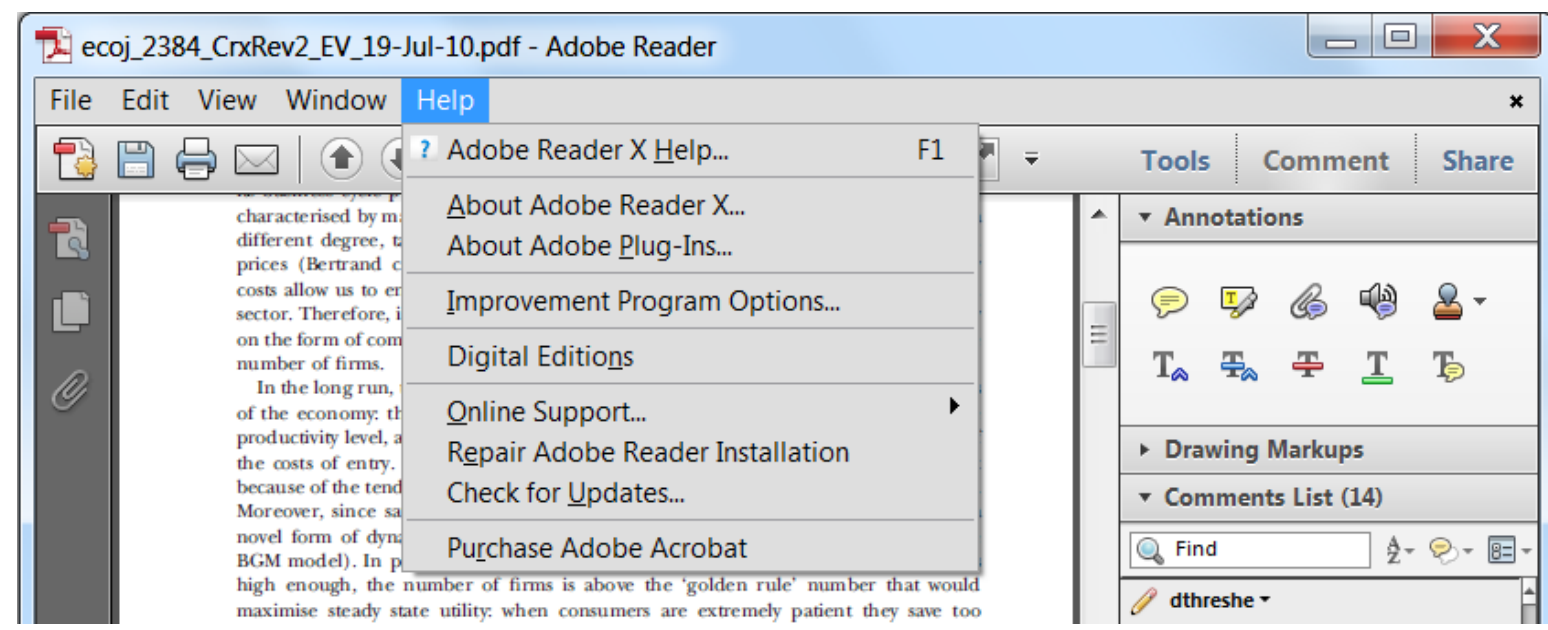

